\title{
Analysis of Brazilian consumer preference of filled chocolate
}

\author{
Aceitação global de bombons recheados pelo consumidor brasileiro
}

\author{
Joice Natali MIQUELIM ${ }^{1 *}$, Jorge Hermann BEHRENS ${ }^{1}$, Suzana Caetano da Silva LANNES ${ }^{1}$
}

\begin{abstract}
Chocolate is the most popular product made from cocoa. It is mainly consumed with fillings, such as fondant, hydrogenated fat or fruits. This work aimed at assessing the sensory acceptability of chocolate filled with strawberry, orange or passion fruit pulps, mixed in fondant, in a hydrogenated fat base and as truffles. Ninety four consumers participated in the test using a $10 \mathrm{~cm}$ hedonic scale to rate the overall liking of the samples. Two-way analysis of variance and the Internal Preference Mapping technique were used to analyze the data. Results showed a good overall liking for almost all samples, especially for strawberry and passion fruit truffles, which obtained 8.4 and 8.8 global means, respectively $(\mathrm{p}<0.05)$, in liking ratings, followed by the hydrogenated fat and fondant fillings. The Internal Preference Map presented two dimensions explaining $72.5 \%$ of the variation found. Regarding the flavors, strawberry - traditional in chocolate and confectionary in Brazil - and passion fruit obtained better acceptance, unlike the orange fillings, which showed significantly lower ratings $(\mathrm{p}<0.05)$. The orange fondant filling obtained a global mean of 6.5 .

Keywords: chocolate; sensory evaluation; consumer; preference mapping.
\end{abstract}

\section{Resumo}

Chocolate é o produto mais popular feito do cacau. Ele é consumido preferencialmente como bombom recheado, com recheios como fondant, gordura vegetal hidrogenada ou frutas. O objetivo deste trabalho foi mapear, através da análise sensorial, a preferência dos consumidores de chocolates recheados com um preparado de frutas nos sabores morango, laranja e maracujá, misturados em bases de açúcar fondant, gordura hidrogenada e na forma de trufas. Noventa e quatro consumidores participaram do teste utilizando uma escala hedônica de $10 \mathrm{~cm}$, dando uma nota relativa nesta escala de acordo com a sua aceitação em relação a cada bombom provado. A ANOVA de dois fatores e a técnica do Mapa de Preferência Interno foram utilizadas para analisar os dados obtidos. Os resultados mostraram uma boa aceitação de todos os produtos, especialmente para as trufas de morango e maracujá, que obtiveram médias globais iguais a 8,4 e 8,8, respectivamente ( $p<0,05)$, seguidas dos bombons recheados em base com gordura hidrogenada e fondant. O mapa de preferência interno apresentou duas dimensões que explicaram $72,5 \%$ da variação encontrada. Sobre os sabores é possível dizer que o morango - tradicional para chocolates e confeitaria no Brasil - e o maracujá obtiveram uma melhor aceitação, o que não ocorreu com o sabor laranja, que mesmo com boas notas globais, quando comparado com os outros sabores obteve menores médias $(\mathrm{p}<0,05)$. O bombom recheado com fondant de laranja obteve uma media de 6,5.

Palavras-chave: chocolate; análise sensorial; consumidor; mapa de preferência.

\section{Introduction}

Chocolate products share consumers' preferences among other confectionery products, not only for their nutritional value, but especially due to their chemical and physical properties perceived by consumers as unique sensory properties. Flavor, brightness and complete melting in the mouth are some of the sensory attributes that contribute to the uniqueness of chocolate (BECKETT, 2000).

Molded chocolates are quite popular and can contain a filled center with fruits, creams, liquors, etc., which makes a contrast in terms of taste and texture (BECKETT, 2000). Either whole or parts of fruits or mixtures with other ingredients can be used as fillings. This combination produces a significant effect on the product's texture, and thus on its acceptability (ANVISA, 1978; BECKETT, 1994; MINIFIE, 1970).

Understanding which sensory properties drive consumer preferences is an important phase in the product development cycle. Through consumer sensory acceptance tests, it is possible to assess liking, and when several products and/or prototypes are compared, preferences come up. In addition, demographic data such as gender, age, educational level and economic and social status can help food marketers determine consumer segments as a function of sensory preferences (THOMPSON et al., 2004, PIGGOTT, 1988; MARSHALL, 1987). Indeed, segmentation is a key point in sensory studies assessing consumer preferences. In this line, Internal Preference Mapping (MDPREF), among other multivariate statistical techniques, is a tool for exploring and understanding the structure and tendencies of consumer preferences. It is often performed to identify groups of consumers with different attitudinal patterns towards a set of products and also permits profiling different segments of consumers by age, gender, eating habits and/or responses to product attributes (WESTAD; HERSLETH; LEA, 2004).

Internal preference mapping is similar to a principal component analysis (PCA) performed on the matrix of hedonic data obtained in a consumer test. Orthogonal sensory dimensions

${ }^{1}$ Departamento de Tecnologia Bioquímico - Farmacêutica, Faculdade de Ciências Farmacêuticas, Universidade de São Paulo - USP, E-mail: jmiquelim@usp.br

${ }^{*}$ A quem a correspondência deve ser enviada 
are derived so that they represent the strength of consumer preferences for different food samples. Like a perceptual map, consumers and their most preferred products are plotted closely in the preference space. Age, gender and economic status can be used to explain and understand the preferences of different consumer segments (GUINARD; UOTANI; SCHILCH, 2001, MCEWAN; THOMSON, 1987).

The present work aimed at assessing the sensory acceptance of nine chocolate samples filled with fondant, hydrogenated fat and truffle, with added fruit pulps - strawberry, passion fruit and orange. Analysis of variance and internal preference mapping were used to analyze the data, in order to better understand consumer preferences for filled chocolates.

\section{Materials and methods}

\subsection{Formulations}

Nine filling formulations (Table 1) were developed based on three major ingredients: hydrogenated fat, fondant and white chocolate (truffle). Fruit mixes prepared with strawberry, passion fruit or orange were added to each of the three bases to produce the fillings.

The fruit mixes were obtained by adding dehydrated or fresh fruits to a sugar syrup made with inverted sugar, glucose syrup and water (proportion of 1:1:1). Preservatives, acids, flavors and colorings were also added (Figure 1).

The fondant fillings were produced by adding the fruit mix to melted fondant sugar and xanthan gum (to promote better stability and adequate viscosity). The hydrogenated fat fillings were obtained by emulsification of the fat with fondant sugar and addition of the fruit mix. The truffles were made by mixing whipped cream with white chocolate, inverted sugar, a preservative agent and the fruit mixes.

Chocolate shells were filled with the fondant and hydrogenated fat fillings. The truffles, being more consistent, were manually molded into balls and covered with chocolate.

\subsection{Sensory evaluation}

Ninety-four consumers, both male and female, recruited at the campus of the University of São Paulo and amongst customers of a confectionery shop in São Paulo, participated in the sensory test. Individuals were recruited after answering a questionnaire based on the model suggested by the IBGE (Brazilian Institute of Geography and Statistics) (http://www.anep.org.br), giving socio-demographic information, as well as the purchase frequency and consumption of chocolate products.

The samples were presented monadically, following a completely randomized block design. Liking was rated using a $10 \mathrm{~cm}$ hybrid hedonic scale $(0=$ dislike extremely, $10=$ like extremely $)$
(MEILGAARD; CIVILLE; CARR, 2001; VILLANUEVA, 2003). All the ninety-four consumers evaluated the 9 samples, but the test was carried out during 10 days and consumers were allowed to evaluate only three samples per day, with an interval between samples of at least 1 hour. Consumers were asked to drink a glass of water before evaluating the samples in order to prevent a carry-over taste.

The data were submitted to a two-way ANOVA (samples and consumers) to determine significant differences $(\mathrm{p}<0.05)$ among the liking mean ratings of the samples. Complementing the analysis, Internal Preference Mapping (MDPREF) (WESTAD; HERSLETH; LEA, 2004; BEHRENS et al., 2004) was also performed on the statistical software SAS for Windows, version 9.1.3.

\section{Results and discussion}

The consumers who participated in the test, both male and female, were mainly young adults, with ages between 18 and 30 (61.7\%), followed by adults between 31 and 50 (21.3\%). Only $10.6 \%$ were under age 18 , and those over age 51 were $6.4 \%$. Most individuals presented a college degree (81\%) and the reported income could be highly correlated with the educational level: $49 \%$ from higher social classes, $44.6 \%$ from middle class and $6.4 \%$ from lower social classes. The consumer profile above showed the market target: young people of a higher economic level, who are potential buyers, looking for quality products (RODRIGUEZ, 2005).

Table 2 presents the mean liking ratings ( $\mathrm{n}=94$ consumers) for each chocolate sample. Significant differences $(\mathrm{p}<0.05)$ were found and the highest acceptance levels were for the passion fruit and strawberry truffles, followed by the orange truffle. Fondant and fat fillings obtained significantly lower acceptance ratings, as

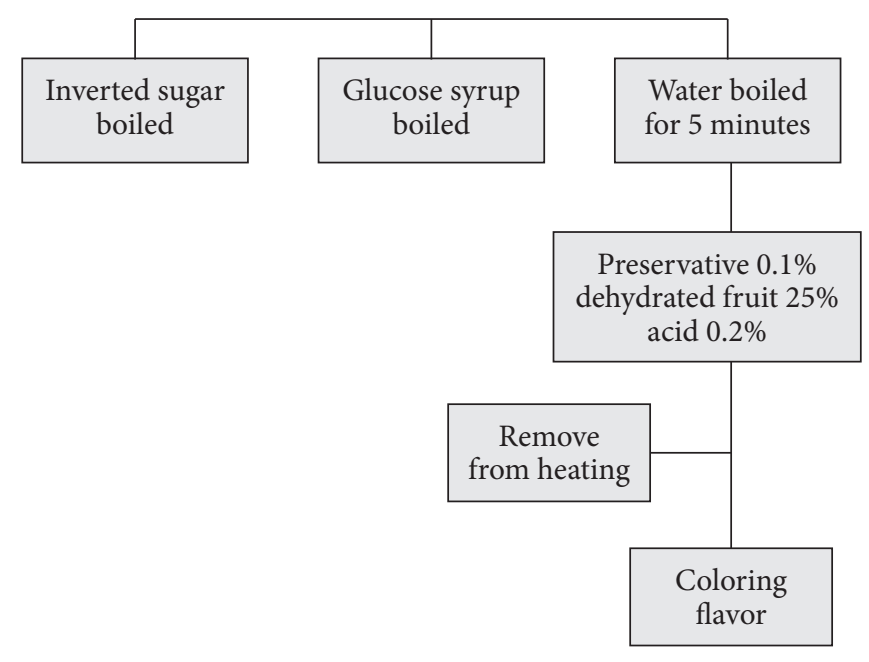

Figure 1. Flow chart of fruit mix preparation (MIQUELIM, 2006).

Table 1. Chocolate formulations.

\begin{tabular}{ccccccccccc}
\hline \multirow{2}{*}{ Filling } & \multicolumn{3}{c}{ Strawberry } & \multicolumn{3}{c}{ Orange } & \multicolumn{2}{c}{ Passion Fruit } \\
\cline { 2 - 9 } & Truffle & Fondant & Fat & Truffle & Fondant & Fat & Truffle & Fondant & Fat \\
\hline Code & F1 & F2 & F3 & F4 & F5 & F6 & F7 & F8 & F9 \\
\hline
\end{tabular}


compared to the truffles. Nevertheless, the results showed that most of the chocolate formulations tested can be considered optimized in terms of sensory quality, presenting, in general, mean ratings equal to or above 7.0 in the hedonic scale.

A possible justification for the high acceptance of truffles (F1, F4 and F7) could be the use of white chocolate and whipped cream in those fillings. Besides, the combination with passion fruit and strawberry must have contributed with pleasant flavors. On the other hand, orange filling seemed not to be so well accepted by consumers, the same occurring with passion fruit fondant.

A common question that normally arises from consumer sensory data is the use of mean calculations to represent the acceptance level of the samples evaluated, from which comparisons are made to infer about preferences. This important issue is substantiated by a number of works on sensory consumer science calling attention to segmentation, especially in studies performed with a large number of consumers assessing several different samples (WESTAD; HERSLETH; LEA, 2004; MEILGAARD; CIVILLE; CARR, 2001; GUINARD; UOTANI; SCHILCH, 2001; JANUSZEWSKA; VIAENE, 2001; ARDITI, 1997). In this line, multivariate statistical techniques should be used as a means of revealing underlying consumer preferences. With this purpose, MDPREF was performed with the data.

Figure 2 presents the internal preference map derived from the 94 individual liking responses for the nine chocolate samples. Samples are separately represented in the first plot (A), followed by the consumers' plot (B). The MDPREF used herein is a vectorial model similar to a principal component analysis (PCA). The algorithm initially computed the intercorrelations among the variables (samples and consumers). Then the data matrix was transformed through estimation of a factor model to obtain a factor matrix. Combinations of the loadings of each variable formed sensory dimensions (like factors on the PCA model), upon which the underlying structures of consumer preferences were represented. The number of dimensions derived in the analysis depends on the extent to which each variable can be explained, so that new dimensions are derived until 100 per cent of the whole variability in liking can be represented. As the first two dimensions account for most of the explanation, they were used to build the biplots showed in Figure 2. The model obtained herein explains $72.5 \%$ of the original liking data, which can be considered a fairly good solution. Dimension 1 accounts for $45 \%$ of the explanation of the relationship between samples and consumer preference, while dimension 2 explains $27.5 \%$. The other dimensions derived in the model did not contribute for significant explanations of the preference and therefore were not used.

The samples plot in Figure 2a shows the truffle samples plotted far apart from chocolates with fat and fondant fillings. Truffle loadings on dimension 1 were high and positive, whereas the loadings of the other samples were negative and on the opposite side of this dimension. Looking at plot (B), it can be seen that most consumers also had positive and high loadings on dimension 1 , evidencing that they were intercorrelated - sharing the same preference pattern - and correlated to the truffle samples or, in other words, their preference.

Dimension 2 contributed to separate chocolates with fat filling (F3, F6 and F9) - positively correlated to dimension 2 - from the fondant fillings (F2, F8 and especially F5) - negatively correlated to dimension 2. Plot (B) shows that very few consumers were located along dimension 2, closer to the chocolates with fondant and fat fillings.

The MDPREF is an interdependence multivariate technique and generates a kind of perceptual map, like in multidimensional scaling and correspondence analysis. The model used in this study neither permits a clear segmentation of consumer responses, nor statistical inferences. Nevertheless, the relationship be-
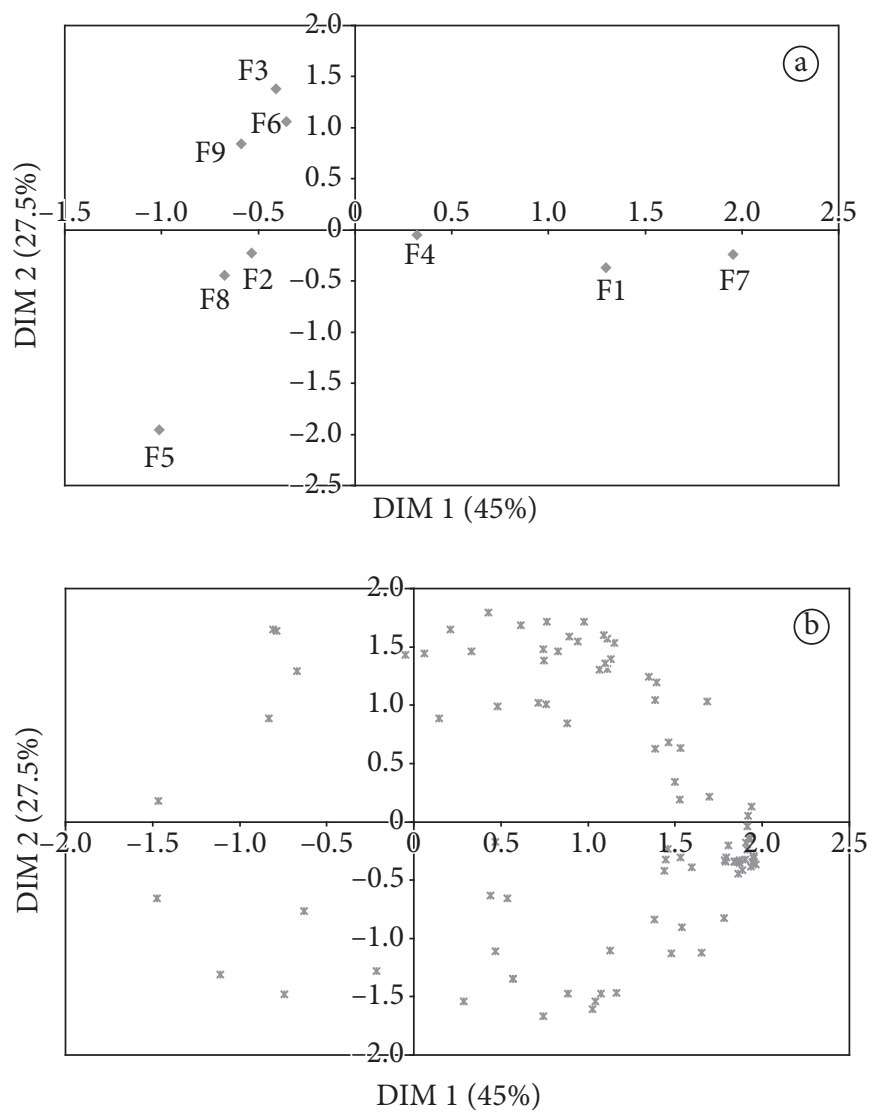

Figure 2. Internal preference mapping for filled chocolates: a) samples plot; and b) consumers plot.

Table 2. Mean overall liking ratings ${ }^{*}$ for each one of the nine chocolate formulations obtained in the sensory evaluation ( $\mathrm{n}=94$ consumers).

\begin{tabular}{ccccccccccc}
\hline Sample & \multicolumn{3}{c}{ Strawberry } & \multicolumn{3}{c}{ Orange } & \multicolumn{2}{c}{ Passion fruit } \\
\cline { 2 - 11 } & Truffle & Fondant & Fat & Truffle & Fondant & Fat & Truffle & Fondant & Fat \\
\cline { 2 - 11 } & F1 & F2 & F3 & F4 & F5 & F6 & F7 & F9 \\
\hline Mean ratings & $8.4^{\text {ab }}$ & $7.0^{\text {bcd }}$ & $7.4^{\text {bc }}$ & $7.7^{\mathrm{b}}$ & $6.5^{\text {d }}$ & $6.8^{\text {cd }}$ & $8.8^{\text {a }}$ & $6.7^{\text {cd }}$ & $7.0^{\text {bc }}$ \\
\hline
\end{tabular}

${ }^{*}$ Means with the same letters do not differ significantly $(\mathrm{p}<0.05)$ according to the Tukey mean comparison test (HSD). 
tween samples and consumers depicted in the plots corroborate the information on Table 2. Truffle samples F7 and F1 obtained significantly higher mean liking ratings $(\mathrm{p}<0.05)$, according to ANOVA and the Tukey mean comparison test. F7 was the most accepted chocolate and this fact is graphically represented in Figure 2a, where F7 is located at a certain distance from the other truffles (F1 and F4), although they did not significantly differ in liking ( $p>0.05)$. About $35 \%$ of consumers are highly correlated to dimension 1 and represented in the same region on the preference space. Therefore, a first conclusion is that F7, a truffle with a filling made with passion fruit pulp obtained the preference of most consumers, followed by the other truffles, with strawberry and orange fillings.

Clearly opposite to F1 is sample F5, a chocolate with orange pulp in fondant filling, which obtained the significantly lowest mean liking rating $(\mathrm{M}=6.5, \mathrm{p}<0.05)$. F5 did not significantly differ from the other fondant fillings (F2 and F8) and the orangeflavored fat filling (F6).

It is interesting to note that the fat fillings (F3, F6 and F9) also obtained high mean liking ratings and no significant differences $(p>0.05)$ among them. Fondant fillings did not differ in acceptance $(p>0.05)$ from fat fillings. Strawberry and passion fruit appeared to be the best options in both fondant and fat fillings - as in the truffles. Thus, a second observation is that fat and fondant fillings could result in chocolates with regular (not good) acceptability.

Orange fruit fillings were not very well accepted, except when mixed with white chocolate and whipped cream.

\section{Conclusions}

The different fillings and fruit pulps used in the formulations directly influenced chocolate acceptability.

Significant differences $(\mathrm{p}<0.05)$ were found and the highest acceptance levels were for the passion fruit and strawberry truffles, followed by the orange truffle.

Fondant and fat fillings obtained significantly lower acceptance ratings, as compared to truffles.

Nevertheless, these results showed that most of the chocolate formulations tested can be considered optimized in terms of sensory quality, presenting, in general, mean ratings equal to or above 7.0 in the hedonic scale.

On the other hand, the fat fillings (F3, F6 and F9) might have been negatively perceived, although the combination with fruit pulps, markedly strawberry and passion fruit, resulted in fairly accepted products. In this sense, fat fillings with strawberry and passion fruit pulps could be a way to produce well-accepted products at a lower cost and with longer shelf-life (fondant and hydrogenated fat fillings presented a shelf-life of up to one year).

Finally, this study evidenced that premium products made with noble ingredients, such as white chocolate and whipped cream, had higher acceptance - and preference - by consumers. However, the shelf-life of these products reaches only three months (MIQUELIM, 2006).

\section{Acknowledgements}

We are grateful to Dr. Nilda D.M. Villanueva, who programmed MDPREF in SAS, and also to CNPq and CAPES Brazilian supporting agencies - for sponsoring this work.

\section{References}

ARDITI, S. Preference mapping: a case study. Food Quality and Preference, v. 8, p. 323-327, 1997.

BECKETT, S. T. Fabricacion y utilizacion industrial del chocolate. Zaragoza: Acribia, 1994. 423 p.

BECKETT, S. T. The science of chocolate. Cambridge: The Royal Society of Chemistry, 2000. 175 p. (RSC paperbacks).

BEHRENS, J. H.; ROIG, S. M.; DA SILVA, M. A. A. P. Fermentation of soymilk by commercial lactic cultures: development of a product with market potential. Acta Alimentaria, v. 33, n. 2, p. 101-109, 2004.

BRASIL. Ministério da Saúde. Agência Nacional de Vigilância Sanitária. Legislação. VisaLegis. Resolução CNNPA n. 12, de 1978. Aprova NORMAS TÉCNICAS ESPECIAIS, do Estado de São Paulo, revistas pela CNNPA, relativas a alimentos (e bebidas), para efeito em todo território brasileiro. Disponível em: <http://e-legis.anvisa.gov.br/ leisref/public/showAct.php?id=16216\&word=>. Acesso em: 9 out. 2005.

BRAZILIAN INSTITUTE OF STATISTICS AND GEOGRAPHY. Critérios de classificação econômica no Brasil - Levantamento sócio- econômico, 2000. Disponível em: <http://www.anep.org. br>. Acesso em: 26 jan. 2005.

GUINARD, J.; UOTANI, B.; SCHILCH, P. Internal and external mapping of preference for commercial lager beers: comparison of hedonic ratings by consumers blind versus with knowledge of brand and price. Food Quality and Preference, v. 12, p. 243-255, 2001.

JANUSZEWSK, A. R.; VIAENE, J. Sensory segments in preference for plain chocolate across Belgium and Poland. Food Quality and Preference, v. 12 , p. 97-107, 2001.

MARSHALL, D. W. Behavioural variables influencing the consumption of fish products. In: THOMSON, D. M. H. (Ed.) Food acceptability. London, New York: Elsevier Science, 1988. 426 p. (Proceedings of the University of Reading - Society of Chemical Industry Symposium on Food Acceptability, University of Reading, 14-18 september 1987).

MCEWAN, J. A.; THOMSON, D. M. H. An Investigation of the Factors Influencing Consumer Acceptance of Chocolate Confectionery Using the Repertory Grid Method. Food Acceptability. Essex, UK: Elsevier Science Publisher, 1987. p 347-361.

MEILGAARD, M.; CIVILLE, G. V.; CARR, B. T. Sensory Evaluation Techniques. Boca Raton, USA: CRC Press, Inc., 2001. p. 281.

MINIFIE, B. W. Chocolate, cocoa and confectionery: Science and technology. Westport: AVI, 1970. 624p.

MIQUELIM, J. N. Avaliação reológica e físico-química de bombons recheados com preparado de morango, laranja e maracujá em base açúcar fondant, gordura hidrogenada e chocolate branco. São Paulo, Brasil: Universidade de São Paulo, 2006. 92 p.

PIGGOTT, J. R. Sensory analysis of food. London: Elsevier Applied Science, 1988. $426 \mathrm{p}$.

RODRIGUEZ, N. C. Creating quality with sensory shelf-life studies. Disponível em: <http://www.fmssinc.com/speaks/articles.html>. Acesso em: 9 out. 2005. 
SAS Institute. Versão 9.1.3. Cary: SAS, 2003. Disponível em: <http:// www.sas.cc.vt.edu/faqlib/SAS_Install.htm $>$. Acesso em: 26 Maio 2005.

THOMPSON, J. L. et al. Preference mapping of commercial chocolate milks. Journal of Food Science, v. 69, p. 406-413, 2004.

VILlAnUEVA, N. D. M. Avaliação do Desempenho de Quatro Métodos de Escalonamento em Testes Sensoriais de Aceitação
Utilizando Modelos Normais Aditivos de Análise de Variância e Mapas Internos de Preferência. Campinas, 2003. 140 p. Tese (Doutorado em Ciência dos Alimentos e Nutrição), Universidade de Campinas - UNICAMP.

WESTAD, F.; HERSLETH, M.; LEA, P. Strategies for consumer segmentation with applications on preference data. Food Quality and Preference, v. 15, p. 681-687, 2004. 